\title{
Housing developers in the context of construction fever in twelfth- and thirteenth-century Catalonia
}

Jordi Morelló Baget

Institute of History, CCHS, Madrid

\section{ABSTRACT}

This article focuses on the different types of people who became housing developers in medieval Catalonia through the assignment in emphyteusis of land for building ("ad construendum domos"). As examples, the article looks at four places of different sizes and jurisdictions which are well enough documented - in some cases with a series of emphyteutic establishments - to permit a diachronic study. In addition to identifying some of the main developers and the kinds of actions they took in each area, the article reviews the beneficiaries of the subsequently allotted or distributed plots, conditions established in the donations, size of plots or other indications regarding construction, materials used, and layout of future dwellings. Although this study is primarily based on published documentary sources, some contributions from the field of archaeology are also considered. Ultimately, it aims to determine the timeline of this phenomenon, that is, the moments when such building activity might have peaked in the context of the demographic and economic growth of the whole period.

\section{KEYWORDS}

Urban planning; developers; emphyteutic leases; burgage plots; new dwellings

During the decades around 1150-1280, a period of demographic and economic growth that coincided with the Romanesque and the early Gothic styles of construction, Catalonia caught the building fever that swept across Western Europe. ${ }^{1}$ Housebuilding was one of the main signs of this trend, and Catalan documentary sources show that many houses were built during this period. This gained ground in all corners of the territory, both in rural areas, through the construction or renovation of masos (farmhouses), and in the small towns or suburbs, the so-called viles noves or pobles created ex novo or next to pre-existing centres of population, where neighbourhoods sprang up outside the old city walls. Not to mention, in some cases, the new walled enclosures that were built and ended

\footnotetext{
${ }^{1}$ This study was fully supported by Petrifying Wealth. The Southern European Shift to Masonry as Collective Investment in Identity, c.1050-1300. This project has received funding from the European Research Council (ERC) under the European Union's Horizon 2020 research and innovation programme (grant agreement $n^{\circ} 695515$ ).
} 
up enveloping the most recently developed areas. This flurry of activity led to many areas being under construction on an almost continuous or permanent basis.

To try to assess the speed, extent, and systematisation of the construction of dwellings could be regarded as a mission impossible unless one resorts to the kind of documentation that gives us chronological sequences, however partial they may be, of the multiple courses of action undertaken in this field (apart, logically, from the assessment of other types of evidence: archaeological, architectural, town planning...); and there is no better yardstick for this purpose than the transfer of land for building houses (ad construendum domos). In addition, knowing exactly who were behind these enterprises whether as the main promoters or as intermediaries, in individual or collective actions, and collaborating or competing with one another - shows us the social dimension of the phenomenon. Both aspects are linked to current historiographical interests, such as the study of the wealth petrification process, in this case circumscribed by everything to do with civil buildings. Non-religious medieval constructions have been paid less attention by historiography because the materiality of buildings is usually conspicuous by its absence; not for nothing does it concern buildings that have vanished over the centuries, and which were built to meet the everyday needs of large sectors of the population rather than for symbolic uses or the ostentation of the wealth of a few.

\section{Planned (or managed) urban development}

Naturally, it was in the cities where most building occurred, impacting the urban topography and rearranging the social and monumental landscape. Cities, according to French historiography, became chantiers or quarries, not only due to the construction of new cathedrals or other (parish or conventual) churches, nor even because former 
aristocratic residences were turned into palaces. The fact is that, compared to the far more symbolic "buildings of power" - which were few and far between - ordinary people's dwellings continued to increase exponentially during the central Middle Ages. To a certain extent, this flurry of house building contributed - far more than the few unique buildings that arose - to the transformation of the landscape, even if poorer or less durable materials were used. As Étienne Hubert pointed out, this had to go through different phases, the first three of which were land occupation, division, and construction, to which the author added another two that he refers to as primary and secondary development. ${ }^{2}$

There seem to have been two models of urban growth, as seen in Barcelona: one in semi-urbanised spaces (with different-sized and -shaped plots) and the other through the creation of new islands, where land was partitioned into more regular or uniformlyshaped plots, ${ }^{3}$ the latter a clear example of planned urban development. Rather than spontaneous processes, these were operations undertaken at the behest of the powerful lay and ecclesiastical landowners. ${ }^{4}$ Indeed, it was in urban settings where the largest number of players were involved. In the case of Barcelona, the main documented developers, in addition to the count-kings and certain private citizens, were the cathedral canons, the Cistercians and the military orders. ${ }^{5}$

\footnotetext{
${ }^{2}$ Hubert, "La construction de la ville," 18. The primary phase would be fined "par la construction de nouvelles enceintes et par l'aménagement d'un réseau de voirie encore sommaire," and the secondary, "par la mise en œuvre d'une politique de grands travaux d'utilité publique destinés également ou surtout à l'embellissement et au décor urbain." ${ }^{3}$ Banks, "L’articulació urbana," 99-100.

${ }^{4}$ This process was neither natural nor organic but the result of various guidelines and decisions, according to Banks, "El creixement físic," 11, and "L'articulació urbana," 99. Along the same lines, Hubert, "La construction de la ville," compares both forms of development, spontaneous and organised. Beyond the towns created from an express founding act, there were many others of "orientated creation," see Farías, "La fundación de villas."

${ }^{5}$ And as in many other cities, each of these religious establishments tended to promote urban development in areas close to where they had their headquarters. By way of a summary, see Guàrdia, "La ciutat de Barcelona," in Pladevall, L'art gòtic, 46-54 and
} 
The transfer of plots of land via emphyteusis became the preferred contract of property developers. ${ }^{6}$ At a time when the adoption of Roman law was still incipient, these transactions were often expressed as donations; a plot of land was transferred in exchange for a down payment and an annual fee (in kind or in cash) and the reservation of other rights typical of the emphyteusis, such as the so-called "fadiga" or right of repurchase. ${ }^{7}$ Often, these leasehold donations specified the purpose for which the land was being transferred, and the expression ad construendum domos, or other similar expressions, was a good indicator of the extent to which house building was being boosted. That did not exclude other initiatives by the great lords, such as simple donations, which did not require benefits in exchange, as they could be made in payment or as a reward for services rendered.

In all these urban development processes, the lords could intervene either directly or by authorising others to allocate plots of land for building. ${ }^{8}$ Broadly speaking, they were large tracts of land that would later be sub-allocated - as building plots - to other

bibliography. For the Templars' urban planning activities, see also Fuguet and Plaza, "L'ordre du Temple," 246.

${ }^{6}$ Emphyteusis was the contract by which a lord gave to another person the useful dominion of a real estate, perpetually or long-term, so as to be improved, while retaining its direct dominion. The importance of emphyteutic contracts spread to Italy and the whole Mediterranean area; according to Hubert, "La construction de la ville," 18: "la concession livellaire ou emphytéotique de terrains non bâtis (...) forme le mode d'accès au logement le plus souvent attesté dans la documentation conservée: c'est par ce biais, semble-t-il, que s'est déroulée pour l'essentiel l'urbanisation de l'espace compris entre les anciennes murailles et les nouvelles enceintes citadines." See also Hubert, "Urbanisation."

${ }^{7}$ It was the lord's right to acquire an emphyteutic property to make it his own direct property again, generally for the same price that one might expect to get from anyone else interested in buying it; if the lord waived this right within a certain period of time (ten days or more), the beneficial owner could sell it to a third party, subject to the same obligations with respect to the direct lord. As can be seen from the documentation of the time, how this right was exercised was gradually defined before it was definitively typified.

${ }^{8}$ One could refer to the licence granted by Abbot Guillem and other members of the collegiate church of Cardona in 1210 to the camerarius to build houses in an enclosed area under the castle walls, Galera, Diplomatari, doc. nos. 310, 380. 
individuals or family groups. Sub-allocation involved large landowners linked to the main lords, such as the ones documented in Girona. ${ }^{9}$ By acting as intermediaries, in practice these individuals came to act as real property developers, and probably became the main beneficiaries of the resulting urban development business.

Another issue worth remembering is all the processes that began as a result of the municipal and exemption charters granted in relation, above all, but not only, to the colonisation of the new territories of New Catalonia. ${ }^{10}$ Many of these charters express their underlying repopulation intentions in generic terms, such as ad construendum et hedificandum atque populandum (for building, edifying and populating). ${ }^{11}$ Yet apart from indicating the tenure status of the future dwellings (regarding the possible payment of a levy or total exemption from charges), not much detail is usually given about how the land was divided into building plots or their size, except in rather specific cases. One example is the municipal charter that King Alfonso II (1162-1196) granted in 1185 to the inhabitants of Vilagrassa, near Tàrrega, which refers to an existing division (sicut iam dividimus) of the spaces intended for houses (domos) and orchards and forage land (farragenales), indicating the respective sizes of each: four poles (astas) wide by eight poles long. ${ }^{12}$ According to Gaspar Feliu, each of these plots would have a surface area of about $439 \mathrm{~m}^{2}$, which is quite large. ${ }^{13}$ One could quote another contemporary example,

\footnotetext{
${ }^{9}$ See Canal et al., "Masoveries," 183. See also the case of Valencia in Torró and Guinot, "De la madîna a la Ciutat," 74-83.

${ }^{10}$ All the municipal charters are, to a greater or lesser extent, examples of plans to reorganise the region based on guidelines issued by the local lords. This is even more evident in the cases of incastellamento, that is, by forcing the population to migrate next to a fortified place, as we shall see in one of the examples discussed below.

${ }^{11}$ Font Rius, Cartas, II:161.

${ }^{12}$ Font Rius, Cartas, I, doc. no. 176, 243-45, and 697-98.

${ }^{13}$ Feliu, "Algunes consideracions," 145-47. In Feliu's opinion, the asta was equivalent to other type of measurement (the dexter of thirteen palms), which would make it $3.055 \mathrm{~m}$, hence the surface area inferred. Yet if we were to consider an asta to be $1.80 \mathrm{~m}$ long, the surface area obtained would be three times smaller $\left(103.68 \mathrm{~m}^{2}\right)$, but closer to the space that a single dwelling with an adjoining vegetable garden would occupy.
} 
like the one that Manuel Riu wrote about: in 1182, a certain Pere Arnau and his family, in exchange for spiritual benefits, gave the canon of Solsona a building plot (unum locum nostrum in quem edificetis et construatis domos de abissi usque ad celum, "one place of ours where you build houses from the ground to the sky") in a village called l'Espluga, which has not been identified yet. The size of the land is stated here, too, but using other measurements: et habet ipsum locum de latitudo VIII brazes et media, in longitudo XVII brazes et media ("this place is eight and a half arms wide by seventeen and a half long"). If a braça was $1.6718 \mathrm{~m}$, the surface area of the building plot would be just under $416 \mathrm{~m}^{2}$ which, according to Riu's commentary, was considerably larger than the surface area of the courtyards of urban houses in the late medieval period. ${ }^{14}$ In this case, no adjoining land was included, but in the absence of other documentary references, it is reasonable to think that, at the behest of this religious establishment, it must have then been subdivided, perhaps in order to build several houses.

Municipal charters represented the first step in occupying land and subsequently building houses, either when they were granted by a lord or else later, as can be seen from consulting emphyteutic leases of plots of land. For example, in the case of Vimbodí (near Montblanc), there are documents from 1190 - 1208 regarding some fifteen land leases (generally termed plateam terre, or a space of land) for building houses. These operations were carried out at the request of Poblet's abbots some time after ownership of the town was transferred to the Cistercian monastery in $1172 .{ }^{15}$

\footnotetext{
${ }^{14}$ Riu, "Documents," doc. no. 2, 355-56. The land in question was bordered on three of the four sides by the donors' land, and there were only two houses built on the eastern side. For the layout and size of the town houses, see Riu-Barrera, "Tipus i evolució de les cases urbanes;" Pladevall, L'art gotic, 146-51.

${ }^{15}$ The most highly valued plot was the one leased to Arnau de Vallferosa and his wife with an entrance fee of thirty solidos and in exchange for the payment of a four solidos fee. See Sans Travé, La colonització, 106-12.
} 
Naturally, these were grants to build on land ex nihilo, from the ground up where nothing had been built before. The nomenclature used to refer to these plots varies in line with the place or period, starting with the most generic (locum/pecia terre) and continuing with others such as solum (terre), platea, patium/pati, and also casal/casalici, this last apparently referring to land located next to buildings. ${ }^{16}$ Boundaries with respect to neighbouring possessions are also often indicated, sometimes in terms of the four cardinal points. Although it would be almost mandatory to measure the size of each transferred plot, the dimensions are rarely specified. As for construction time, only a few documents set deadlines for the completion of the work; in this respect, how long it took to build would clearly depend on the type of material used (stone, wood, adobe, etc.) and the construction techniques associated with these materials. Finally, one question that remains unanswered is who would actually build the house: was everyone who took over a plot of land capable of erecting a building on their own, or would they do so with the help and advice of relatives, neighbours, or professional builders? The answers to some of these questions can be suggested on the basis of the four examples discussed in this article.

Each example is very different from the others, and all were chosen for different reasons, either because they offer unusual information (or, in some aspects, more detailed information), or because they can be used to study longer periods of time, based on the series of building plots, which in a way can serve to gauge the extent of the period's building boom. Depending on the documentation available, special attention can be paid to the processes involved in the second and third urban development planning phases indicated by Hubert, i.e., how building plots were divided up and what type of houses could have been built on these plots. The first example deals with the city of Tortosa, next

\footnotetext{
${ }^{16}$ Banks, "El creixement," 18. The land was therefore suitable for building houses.
} 
to the Ebro River, leaving the case of the Saint-Mathieu district of Perpignan, in the far north of the country, until the end; in between, we will look at other inland enclaves, such as Guissona, a town located in an ancient Roman city, and other towns located to the north of Lleida (Riudovelles/Castellnou), which were created, to a certain extent, ex novo (Figure 1).

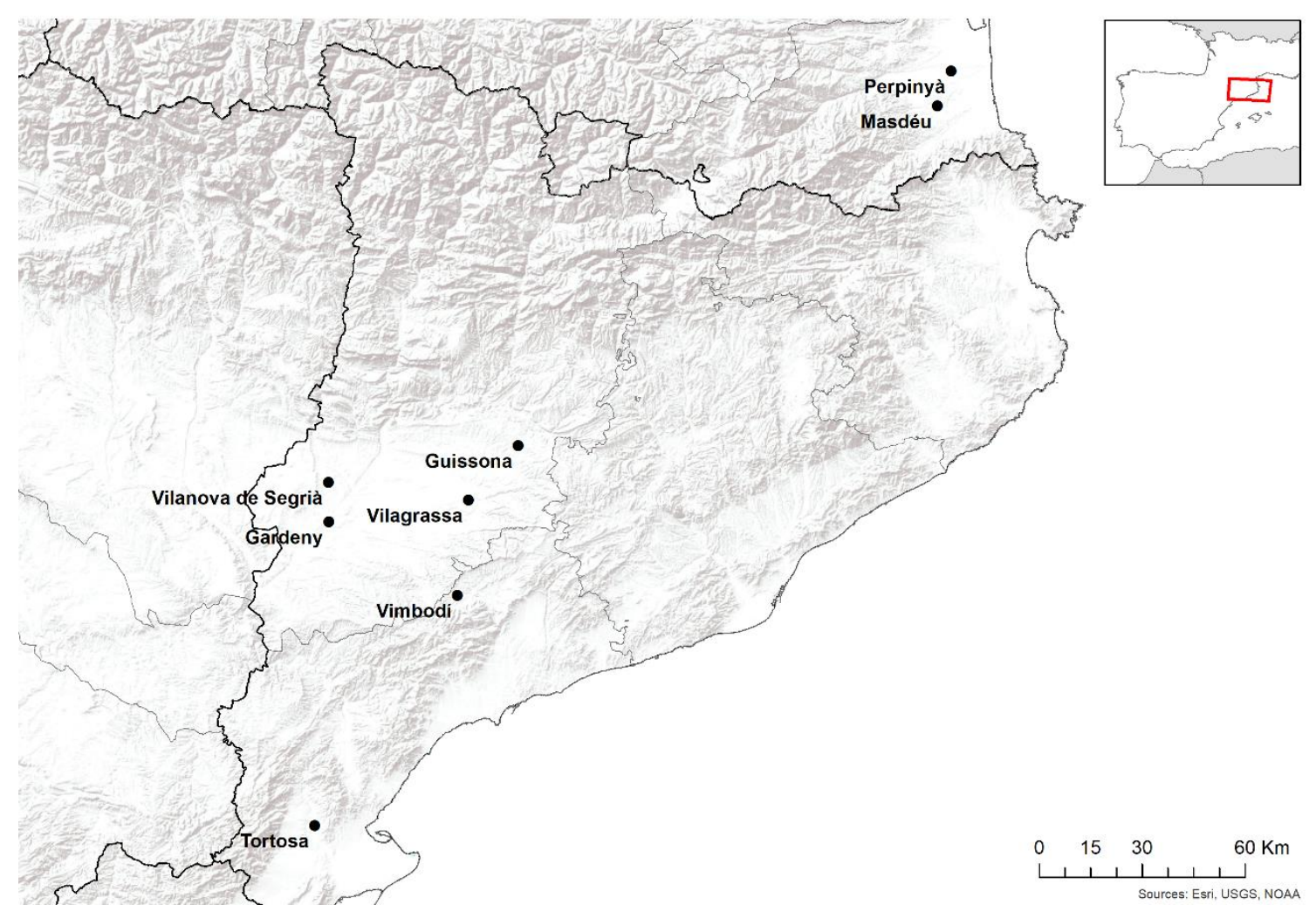

Figure 1. Locations of the enclaves mentioned. Elaboration by Enrique Capdevila Montes, IHCSIC

The selection of these four cases is conditioned by the type of sources consulted. Given that most of this documentation is attributable to initiatives of religious institutions, it leaves the role of other lay actors in the background. This does not, however, mean that they did not play an equally important role as promoters of developable land, but that religious institutions had the ability to better preserve the documentation generated as a result of their acts of establishing land for building.

\section{Tortosa: in the hands of different parties}


After the conquest of Tortosa in 1149, the ancient Andalusi city was shared out among several lords: the crown, starting with Count Ramon Berenguer IV; the noble family of the Montcada and the Knights Templar (both until the end of the thirteenth century); as well as the bishop of the new cathedral. In principle, they would have been the main parties interested in promoting the city's urban development but, judging by the documentary sources available to us, some were more active than others.

The information extracted from the historic collections of the cathedral's charters published to date has been used to document up to fifty-two land-related building transactions completed over a hundred years, 1168-1271. At first glance, this cannot be considered a very high number if one compares it, for example, with the seventy-eight contracts found in Girona for the thirteenth century alone. ${ }^{17}$ Nonetheless, it is a large enough number to suggest the sorts of trends that were followed in the urban expansion of the previously Andalusi city, especially in the new neighbourhoods outside the walls; $;^{18}$ in this respect, there were plenty of donations in the Alfòndec (the commercial neighbourhood next to the river) or in nearby areas such as La Grassa (around the La Seo hospital) and what was known as Vilanova, all in the southern sector; meanwhile, far less building went on in the northern area, known as Remolins, which came to include the Muslim and Jewish quarters (Figure 2).

${ }^{17}$ Canal et al., "Masoveries," 83-106.

${ }^{18}$ According to Pagarolas, Els templers, 38-40, the city grew in two directions: towards the north (Vimpeçol gate) and towards the south, the area of the so-called Alfòndec, which was later replaced by the Llotja, both buildings for corn exchange. 


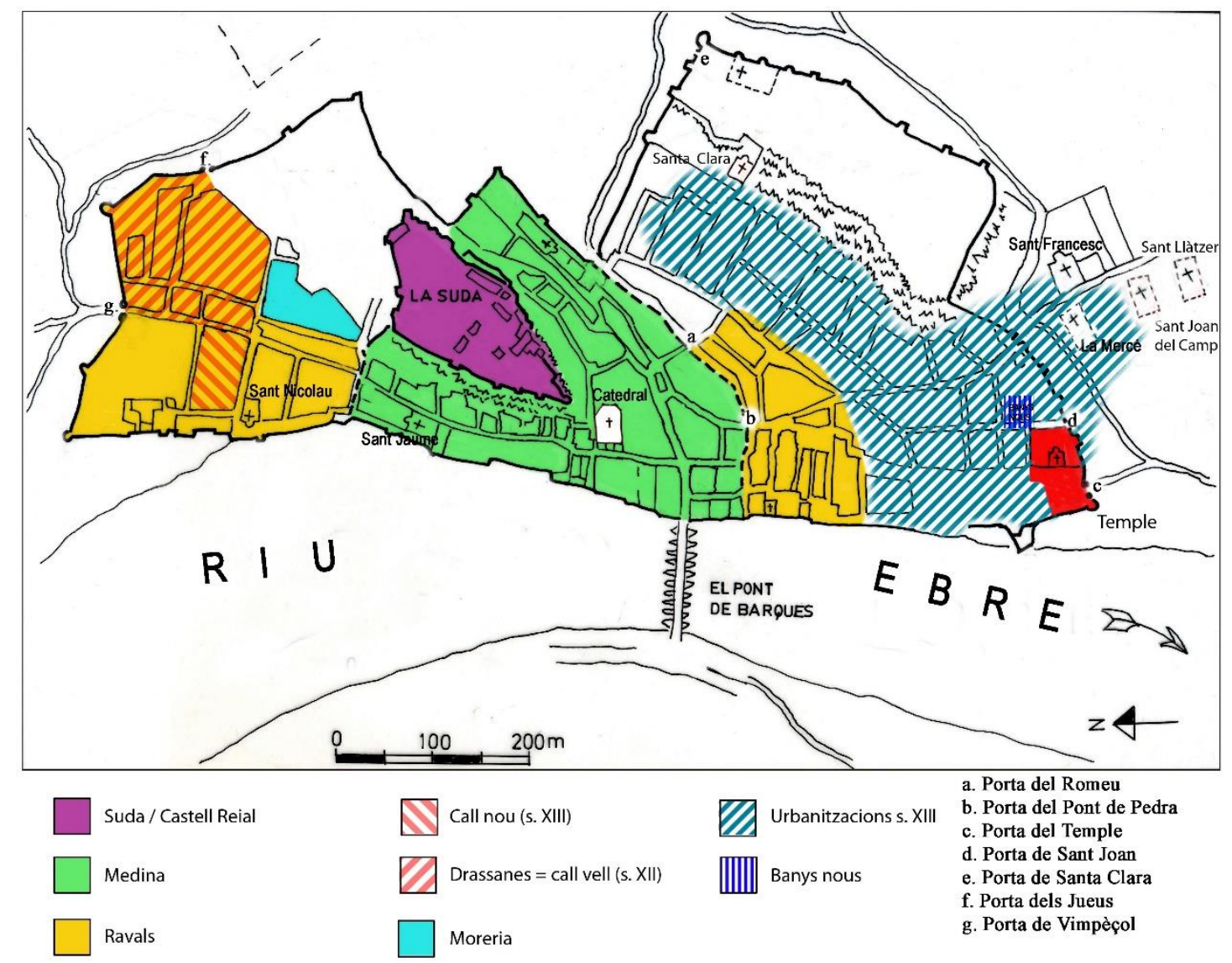

Figure 2. Map of Tortosa, thirteenth-fourteenth centuries. Source: Fuguet and Plaza, "L'ordre du Temple," 252.

Next, we will look at the information provided by the establishment or donation of plots of land, which in Tortosa were known as platea ${ }^{19}$ The developers involved in these transactions were both laity and clerics, the latter much more frequently. One of most prominent laymen was the nobleman Ramon I de Montcada - son of the seneschal Guillem Ramon, one of the main beneficiaries of the first distribution of the city - who, with the consent of the Knights Templar in their role as fellow lords of Tortosa, made a pair of donations in 1187 and 1188; these plots were located outside the city walls and

${ }^{19}$ On the first period of expanding urban development, see Virgili, "Ad detrimentum Yspanie," esp. 194-96. He noted that at the end of the twelfth century, numerous plots of land were granted ad edificandum (for building up), and Table 5 lists fifteen cases. My ongoing research has produced a rather more comprehensive list of the number of donations made at that time. 
near the casa dels malalts (the house of the sick). ${ }^{20}$ Other lay donors were of knightly descent, and were therefore of a much more modest social status; Berenguer Garidell and Pere Arnau de Granada made donations in 1183 and 1188 respectively. ${ }^{21}$ Worth highlighting most of all is the case of Arnau d'Arenys, who owned numerous properties in the Tortosa area. He was also active as a promoter of urban development: he made three donations, two in $1187^{22}$ and one in 1200 , in this case to build a plot next to a house that had already been built. The land was also located outside the city walls, in La Grassa. The conclusion drawn from the boundaries is that there were other beneficiaries in the same area, but their donation documents have not been preserved.

Later records from 1238 and 1245 refer to farmyards in Remolins being donated for conversion into dwellings, ${ }^{23}$ as well as the donation made in 1271 by the prior Pere de Puig of what must have been a portion of the Corral del Prior, in the area of the Alfòndec. ${ }^{24}$ This transaction dates to mid-October of that year, but the corresponding fee would begin to be paid from All Saints' Day of the following year, that is, on 1 November.

As for the Templars, there is little information on donations of the kind we are interested in here, but this does not mean that they did not play a notable role in developing new housing. To begin with, we can mention the place (locum et terram) that the bishop and prior of La Seo granted to the Order in 1190. This land was located in the

\footnotetext{
${ }^{20}$ Virgili, Diplomatari, doc. nos. 406 and 427.

${ }^{21}$ Virgili, Diplomatari, doc. nos. 357 and 425. On the origin of the Granada and Garidell families and their establishment in the city and its surroundings, see Virgili, "Els conqueridors," 267-72.

${ }^{22}$ Virgili, Diplomatari, doc. nos. 417, 418 and 601.

${ }^{23}$ Virgili, Diplomatari, doc. nos. 975 and 1067.

${ }^{24}$ Virgili, Diplomatari, doc. no. 1231.
} 
cathedral's cemetery, outside the walls, and next to the lepers' garden). ${ }^{25}$ However, there is no mention of the reason for the transaction.

According to Pagarolas, the Templars owned properties throughout the city, with houses and plots of land in the area of Sant Nicolau, La Seo, Remolins, and the Alfòndec, and also next to the Casa del Temple. ${ }^{26}$ Taking as a reference the list given by the same author for the thirteenth century, a first grant is recorded in 1246 (involving a plot of land located in the orchard of the so-called Corral belonging to the Order), two more in the Alfòndec (granted in 1273), and another assigned in the same way in the aforementioned Corral (1281). ${ }^{27}$ All of them were plots of land given in order to build houses. Yet these are only four examples for the whole century. In addition to the Temple, there were other military orders with real estate interests in Tortosa. For example, there is evidence of another donation made in 1195, in this case by the prior of the Holy Sepulchre, of a plot of land (platea) located next to the Vimpeçol gate (Remolins), within the walled enclosure, to build houses next to the ones that the Order already owned in the area. ${ }^{28}$

However, the main party behind the development of building plots was the cathedral, whether the bishop, ${ }^{29}$ the prior, or other members of the chapter (acting alone or corporately). In the first stage, documents refer to the prior Ponç, and later to Bernat de Torre, who appears to have acted as the bishop's lieutenant; also worth noting is the case of the hospital canon Vicenç with respect to a series of donations made in 1193, most

\footnotetext{
${ }^{25}$ Virgili, Diplomatari, doc. no 443. Also in Pagarolas, "La Comanda," doc. no. 98.

${ }^{26}$ This house, together with the church of Santa Maria del Temple, was located in the southern sector, outside the walls and close to the river.

${ }^{27}$ Pagarolas, Els templers, 264-66, 269.

${ }^{28}$ Alturo, L'Arxiu antic, doc. no. 615, 185-86. It was donated to Joan Reboster, with the obligation to pay a fee of one morabatí. The properties of the order in the Remolins district date back to a count's donation in 1148, see Virgili, "Ad detrimentum Yspanie," 84.

${ }^{29}$ Above all during the episcopacies of Ponç de Monells (1165-1193) and Ponç de Torrella (1212-1254), and to a lesser extent that of Gombau de Santa Oliva (1194-1212).
} 
of them in La Grassa and in the vicinity of the hospital. In more general terms, the plots granted by the bishop or chapter were located outside the walls, in the Alfòndec (or, more specifically, in the vila nova), in La Grassa (not far from the Alfòndec), and also in Remolins. The few plots inside the walls are in the area of the Suda, the old Muslim fortification. Most of the beneficiaries of these donations were lay people, although they also included members of the cathedral itself; for example, the records show that in 1249 the bishop and the prior made a donation to the sacristan Arnau who, as a reward for his services to the cathedral of Tortosa, was given a plot of land that had been a cemetery (plateam illam que quondam fuit ciminterium), next to ecclesiastical hospital in La Grassa. ${ }^{30}$ The plot bordered on several public roads, some of which led to the river, as well as the houses or properties, on the west side, of at least five people, which gives an idea that the area was already fairly well developed. Although the reason for the donation is not given in this case, it is likely that the land was used to develop the rest of this sector.

In short, apart from the donations made during the first phase of the Christian occupation of the city with respect to the properties owned by the former Muslim inhabitants, ${ }^{31}$ it is clear that, from the end of the twelfth century and throughout the thirteenth, new dwellings began to be built in the suburbs around the old Andalusi city. This was driven, above all, by the bishops and other canons, but also by the participation of other ecclesiastical and lay lords, who seem to have played a less important role, according to the documentation available.

\footnotetext{
${ }^{30}$ Virgili, Diplomatari, doc. no. 1110.

${ }^{31}$ This included turning mosques into dwellings: in 1181 the bishop donated the mosque in Remolins to Ramon d'Aguiló and his wife Ferrera, so that they could build houses in exchange for an annual census of twelve Jaca pennies and a thirty-day right of repurchase.
} 


\section{Guissona: the canonry that promoted the town's growth}

Despite initially maintaining the ancient title of civitas, Guissona developed in a similar way to other towns, around a castle and a church, in this case the Augustinian collegiate church founded in the eleventh century at the behest of La Seu d'Urgell (Figure 3). The documentation compiled mainly by Domènec Sangés for an extensive period of time clearly shows how this institution promoted the building of plots of land in the town itself. ${ }^{32}$ According to surviving documents, it was above all between 1189-1226 when the successive priors who led this community leased a series of plots of land - a total of six. ${ }^{33}$ Another series of plots were leased in a single year (1283), in this case at the request of the sacristan, the precentor, and other canons, with the approval of the bishop of Urgell.

32 Originally built on the ancient site of a Roman city, the town began to develop from the end of the twelfth century onwards, coinciding with the foundation of the first hospital, and especially throughout the thirteenth century. The canonry was also lord of the castle, which was held by several castlans, subordinate to the canons.

${ }^{33}$ For the years $1189,1190,1194,1205,1225$, and 1226. 


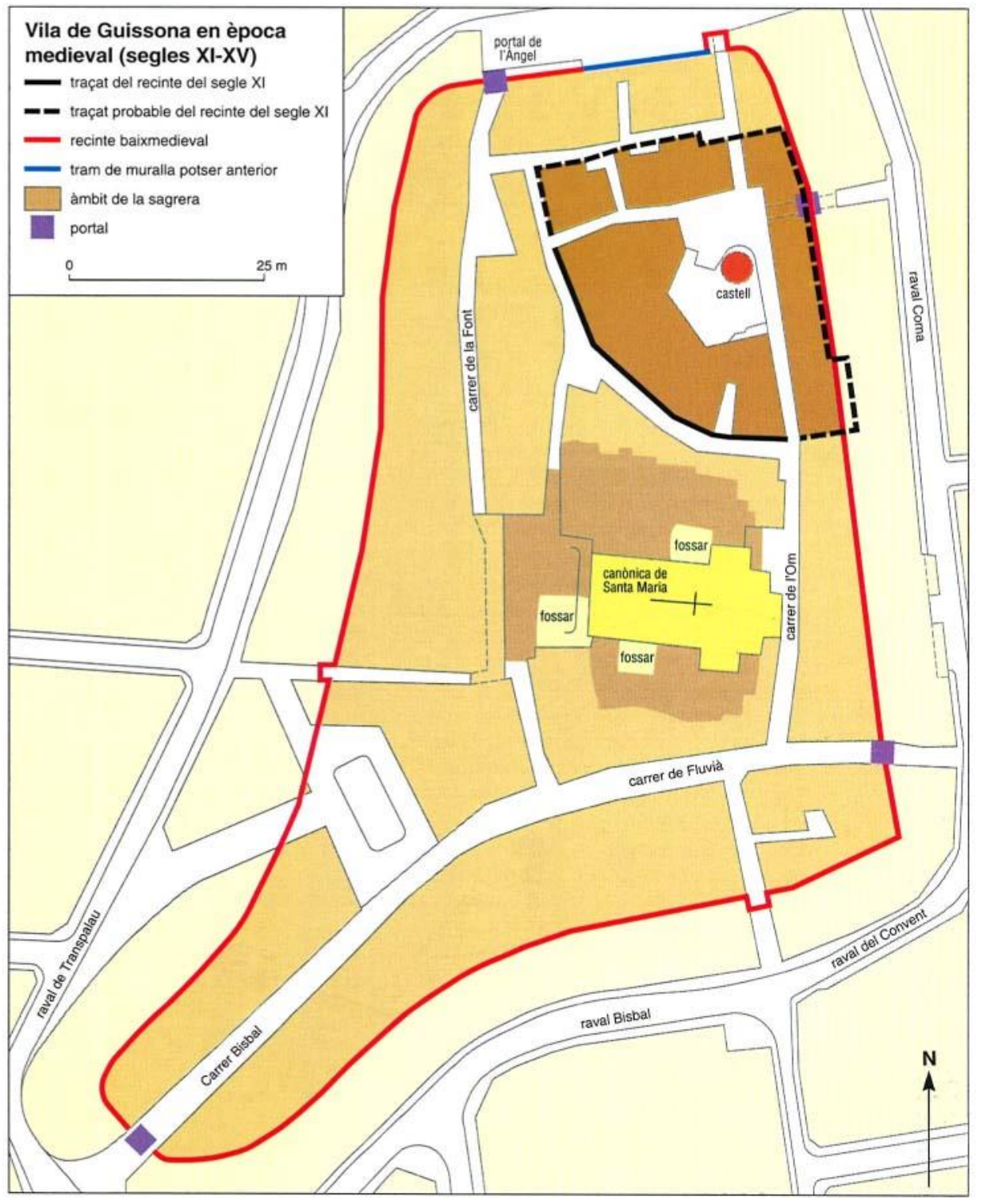

Figure 3. The medieval town of Guissona. Source: Oliva and Ros, Catalunya Romànica, vol. XXIV, Enciclopèdia Catalana, 1997.

The first six were plots of land close to or bordering other properties owned by the canonry, with an orchard, a farmyard, or other houses belonging to Santa Maria de Guissona. In each case, one solum de terra was leased, except for the casalicium indicated in doc. no. 330. These plots were given not only for building houses, since there are four donations that also foresaw the construction of a solarium, ${ }^{34}$ which refers,

${ }^{34}$ And other complementary elements: solarium cum ampitibus (a building space with sills), and anpitus super ipsum murum (a sill on the wall). See Sangés, "Els documents," doc. nos. 403 and 330. 
it seems, to a terrace or superstructure without a roof. Most of these plots were given to couples, except for one whose beneficiary was a clergyman. ${ }^{35}$ With respect to the fees initially recorded in kind (hens and loaves), in the thirteenth century they were in cash (two or three Agramont solidos), although accompanied by a tot nodriment tithe in relation to the animals that were bred in the house. The only record of down payments is to be found in the last two leases of 1225 and 1226, for one and two morabatins, equivalent to seven and fourteen solidos, respectively. In view of the number of donations recorded in those decades, one cannot assume that many houses were being built; even so, it is enough to show that the town must only have grown on the land owned by the canonry, which was the main, if not the only, developer behind the building of dwellings.

The donations made in 1283 - all dated 29 June — served a dual purpose, as we shall see. They were plots of land located in the canons' orchard. Once again, the donations came with the usual emphyteutic conditions. The down payments ranged from thirty Barcelona solidos (three leases) to forty (one) and sixty (two), totalling 250 solidos. By contrast, there was no difference in the fees (which were all ten solidos) and were paid in September for the feast of St Michael. The real difference between these and the previous donations was that the houses had to be built with an annexe for installing several taules or stalls for selling goods, such as meat; obviously, this would refer to the establishment of a butcher shop, which only appears in populations of a certain importance. All the plots of land bordered on a public road and, in at least one case, on the market, the existence of which is attested to as early as the eleventh

35 Sangés, "Els documents," doc. no. 264. This was the presbyter Ramon de Claret, probably a relative of the prior Guillem de Claret. 
century. So, the houses built in this area could have given rise to a small commercial district, and boosted the town's economy for the canonry's own benefit.

\section{Riudovelles/Castellnou: two examples of Templar leadership in rural areas}

Both place names are linked to the origins of Vilanova de Segrià, a small town located to the north of the city of Lleida. ${ }^{36}$ The Templar house of Gardeny was the driving force behind this area's repopulation. Proof of this is that in a document dated 7 July 1193 , Master Ponç de Rigald, together with the other friars, donated a plateam in Riudovelles to a series of settlers (up to sixty-three) to build a series of rural houses (capdemanssa). ${ }^{37}$ Apparently, the idea was to bring the population that until then had lived scattered throughout the area into several fortified villages or "towers," and concentrate them here, where there was already a pre-existing villa located not far from a church dedicated to Santa Maria and a mansion owned by the Temple itself. ${ }^{38}$ Although at the time the term capud mansum was normally used to describe rural estates, in this case it was a question of erecting adjoining buildings (de celo usque in abissum, that is, the formula "from the ground to the sky," but inverted) to form a fairly compact centre of population. At least four of these plots were in the vila vella, but the rest formed a new cluster further away from the original centre of the old town.

36 The exact location of Riudovelles is uncertain; it was located near the rocks of Avimpèlec, which are more than a kilometre and a half to the north of the present-day village of Vilanova. Castellnou is near the ruins of the castle, located on a small hill about $500 \mathrm{~m}$ from the church of Vilanova.

${ }^{37}$ Sarobe, Col-lecció, doc. no. 613.

${ }^{38}$ Riudovelles, which was documented as early as 1168 , was also considered a tower. These "towers" were a form of territorial organisation inherited from the Andalusi period: see Eritja, "De l'Almunia a la Turris." See also a reconstruction of the area on the map in Bolòs, "Els orígens," 88. 
The document in question records the name of the person who was awarded each plot, and there are as many as seventy-nine capdemanssa, as some received more than one. In particular, Bernat Berenguer was awarded five plots; Bernat de Riudovelles, four; and Joan Berenguer, the former's cousin; and Bernat Martí, were each given three. A few others (Miró Basset, Pere Rabad, Joan Conill, Ferrer de Buada, and Miró Guilabert) received two plots each; all the rest — that is, the great majority, including some womenhad to make do with a single plot. We do not know whether each capdemanssum was the same size, as no measurements are specified. In any case, the foundations were being laid for socio-economic differentiation within the newly created neighbourhood community. It seems that some of these settlers already had land there, due to the fact that they had moved there from the surrounding villages, although they may also have come from further away. ${ }^{39}$ Some of them must have been families that were encouraged by the Templars to move to the new place. The historianVirgili has highlighted the role played by Riudovelles in colonising the Segrià area, specifically with regard to Guillem Berenguer de Riudovelles, who ended up with a wealth of land and mills in several parts of the area; as well as being associated with other characters active in similar transactions, he also served as a bailiff for the Order in Riudovelles itself. ${ }^{40}$

Going into a little more detail about the boundaries marked for each plot, one can see that most of them were located next to one, two, or even three streets. ${ }^{41}$ Some plots

39 There is, for example, a Domènec d'Almenara, a Guillem de Casserres, an Arnau de Rialb, and a Pere de Barcelona. However, these do not necessarily have to be direct references to place names of origin.

${ }^{40}$ Virgili, "Els conqueridors," 277-79. Based on this information, it is likely that, in addition to Bernat de Riudovelles, the two aforementioned brothers with the surname Berenguer were part of the same clan, whose name appears directly associated with that town.

${ }^{41}$ In a few cases, it says via que itur apud Sanctam Mariam (the path that goes to Santa Maria) or the via travessera (sic) que itur ante ecclesiam (the crossroad that goes in front of the church), see note 37. 
bordered an irrigation canal (brazalle) derived from another main one. ${ }^{42}$ There is also a mention of the "plaza" of Santa María, meaning the land that must have belonged to the parish. The different boundaries include some threshing floors, as well as the Temple mansion, next to the neighbourhood of the same name; more specifically, reference is made to the albachar de Manssione, located in the primitive town centre. ${ }^{43}$ There is also a mention of another neighbourhood (the Galliners or "Galines"), in this case as a boundary present in eight plots. This might be indicative of different groupings or of a polynuclear configuration.

There were already oil mills (torculariis) on the site, as indicated on some of the boundaries. In addition, the new town was to have butcher shops, a blacksmith, and a furnace maintained by the Templars, for which the inhabitants were to be charged a certain baking fee. Apart from these monopolies, the document in question did not envisage the payment to any kind of fee; moreover, the Temple dispensed with claiming other emphyteutic rights, such as the fadiga (right to repurchase) and the laudemium charged on the price of the property transferred, ${ }^{44}$ reserving only the domain and the rights of administration of justice, together with the retention of a "plaza" for its own use. In short, this seems to show that the lords planned it all, with all the community facilities and services necessary to set up the new town that was to emerge after the plots of land were redistributed.

\footnotetext{
${ }^{42}$ Regarding the canals in the area, see Bolòs, "Paisatge," 65. Indeed, based on the "Capbreus" (documents acknowledging feudal rights) studied by this author, dated 1214, it is clear most of the district of Riudovelles (80\%) was irrigated land.

43 Bolòs, "Paisatge," 52. The term was mentioned as early as 1168 and has been interpreted as meaning a walled enclosure for the protection of people and/or animals.

${ }^{44}$ On the condition that these plots were not transferred to military or ecclesiastical personnel, a clause that had become very common by this time.
} 
However, it is possible that the repopulation of Riudovelles did not quite meet all expectations, as years later in 1231, the Knights Templar of Gardeny promoted another operation by donating a hill in the same area on which to build a new town (ad villam construendam sive edificandam), which was given the name of Castellnou. ${ }^{45}$ The inhabitants of various villages in the area were also called upon to take part, including the inhabitants of Riudovelles, the only enclave of all those mentioned that was no longer described as a "tower." The new inhabitants had to build houses on their new plots or farms (quod faciatis ibi ... caputmansa et domos et domiculas et mansiones...). Unlike the aforementioned example, it was to be a fortified place, surrounded by a wall, and each inhabitant would help build it in accordance with their percentage allotment (secundum quod capudmansa vel staticam tenuerit / according to the tenure received. ${ }^{46}$

In short, the case of Castellnou seems to have been a new attempt to regroup the area's population somewhere higher, and specialists consider it to be a typical case of "incastellamento," understanding for this the concentration of population around castles. For his part, Font Rius postulated the more than possible failure of such a repopulation; however, if Castellnou did not prosper as expected, Vilanova de Riudovelles (now called Vilanova de Segrià) would. ${ }^{47}$ From then on, Castellnou and Vilanova coexisted as two separate entities, although most of the population stayed in Vilanova de Riudovelles (Figure 4).

\footnotetext{
45 Font Rius, Cartas, I, doc. no. 256, 365-67, and 814-15. Contrary to what Bolòs maintains in "Paisatge," 53, and Els orígens, 224, Font Rius did not believe that it was Vilanova de Segrià; actually, in the population censuses of the fourteenth century, both entities were counted separately.

46 See note 45. Apart from this, the Order reserved two plots of land, one for the manufacture of a bread oven and the other, next to the wall, for building houses.

47 All authors consulted consider Vilanova de Segrià to date to the 1231 transaction, omitting the precedent of 1193. Present-day Vilanova de Segrià is dominated by the parish church dedicated to San Sebastià (formerly Santa Maria); as has been seen, the town's old church was related to the "vila vella," that is, to the original Riudovelles.
} 


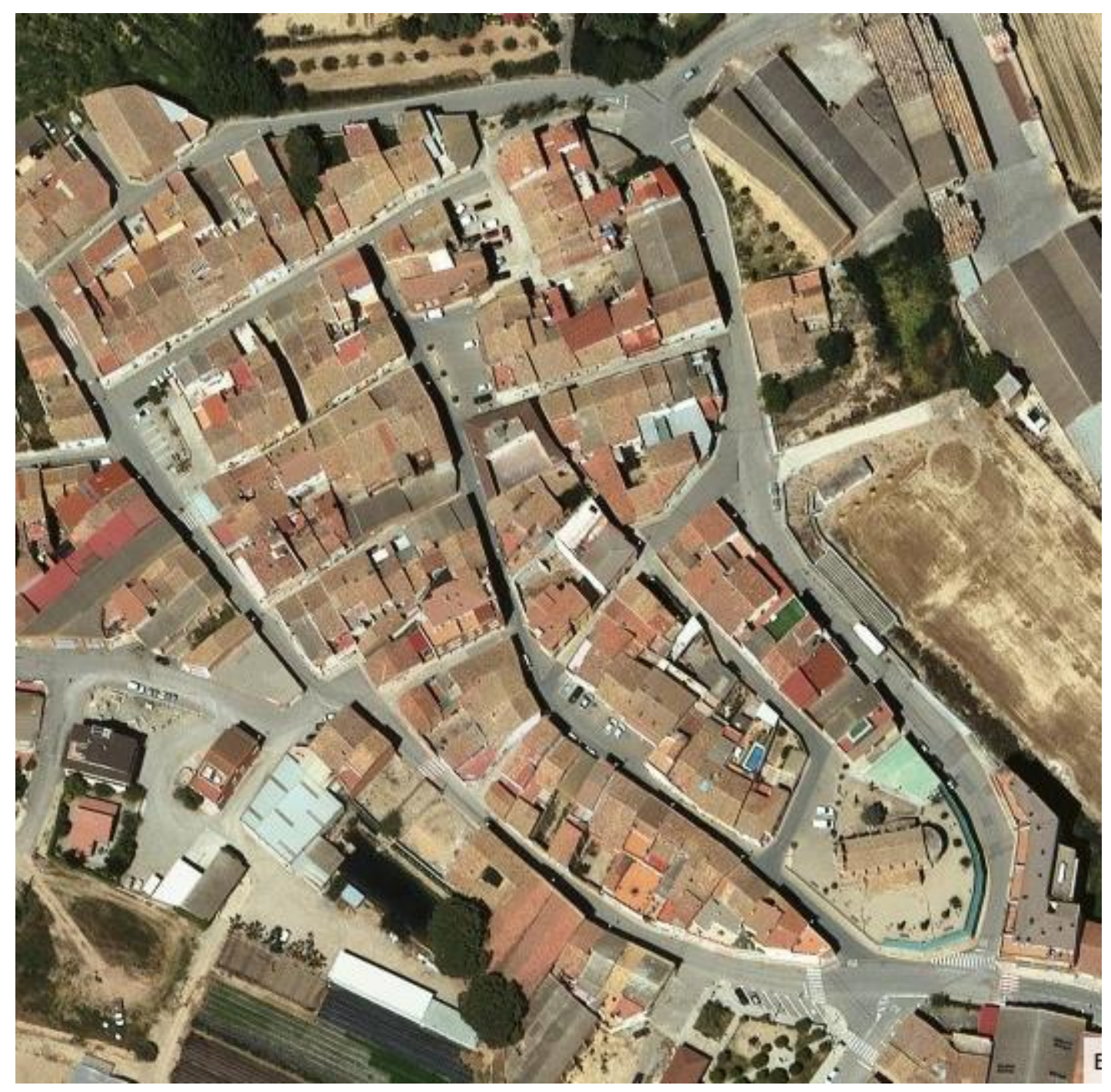

Figure 4. Vilanova de Segrià today. Aerial view of the old town with a possible distinction between two sectors: the original town, next to the church, and the "vila nova" that sprang up when the original town was extended. Source: Institut Cartogràfic i Geològic de Catalunya.

The Templars, in addition to boosting the colonisation of rural areas, also played a very active role in certain town planning processes, such as the one we will deal with below. 


\section{Saint-Mathieu in Perpignan, a paradigm of planned urban development ${ }^{48}$}

Perpignan's urban expansion during the thirteenth century was limited to three areas or districts: La Reial, Sant Jaume, and Saint Mathieu. The latter, initially known as Sant Francesc, was the result of everything that the Templar house of Masdéu planned and did throughout that century. ${ }^{49}$ The Templars parcelled out all the land that they gradually acquired in this area adjoining the town - the parish of Sant Joan - from the gate leading out of the town to the Malloles road, and adjoining another area owned by the Franciscan friars. ${ }^{50}$ What strikes one most is the size of the operation, as can be seen from the large number of leases registered: they donated at least 273 leases on developable land in the area. ${ }^{51}$

In contractual terms, the records always refer to ad accapitum/en acapte donations (from the Latin accapitare, used in the sense of taking something), but despite the different names, the type of notarial instrument was similar to the lease donations we have seen so far. So apart from other extraordinary information, we find the usual clauses of the emphyteutic contracts regarding the right of entry, leases, and fadigas, which vary, depending on the period, from a minimum of ten to a maximum of sixty days.

\footnotetext{
${ }^{48}$ Several local historians have dealt with the subject, in particular Tréton, Diplomatari del Masdéu, I:137-43; Tréton, "L’ordre du Temple," 233-35; Verdon, "Le quartier de Saint-Mathieu;" Vinas, "Els templers," 71-73. From an archaeological point of view, see Rémy et al., "Des maisons en terre." In the present study I summarise some of their results, going into more detail on information provided by the magnificent series of emphyteutic establishments contained in the aforementioned historic collection.

${ }^{49}$ Masdéu is located some ten $\mathrm{km}$ south of Perpignan. Today, all that remains of the former Templar command post founded in 1132 are ruins.

${ }^{50}$ Rémy et al., "Des maisons en terre," 56. The location was no coincidence, because it was the closest area to the house owned by the Temple next to the gate, inside the walled enclosure, and it was the road that led to Malloles, one of the main villages where the Order had possessions.

${ }^{51}$ Or as many as 311, according to Rémy et al., "Des maisons en terre," 55. I rely exclusively on the information extracted from Tréton's historic collection; I do not include mixed grants of houses and courtyards or other kinds of documents.
} 
These donations were made by the entire Templar community, headed or represented by the so-called preceptors of the Masdéu and Perpignan, acting jointly more often than not. ${ }^{52}$ Apart from the first donations made in 1215 by Fra Balaguer (only three are recorded), it was from 1241 onwards that donations were made on a more continuous basis. As can be seen in Graph 1, although the number of leases went up and down, the following years stand out: 1241 (twenty-five establishments) and 1246 (twenty-eight), even more so in 1268 (thirty-four), and especially in 1271, when no less than seventy-one leases were recorded, in this case carried out especially at the request of Fra Pere Sabater as the preceptor of Perpignan. From then on, this type of activity declined until it disappeared altogether in the 1280s. So, there were two main periods: 1241-1251 and 1263-1284 (ignoring some years for which there are no records of any lease).

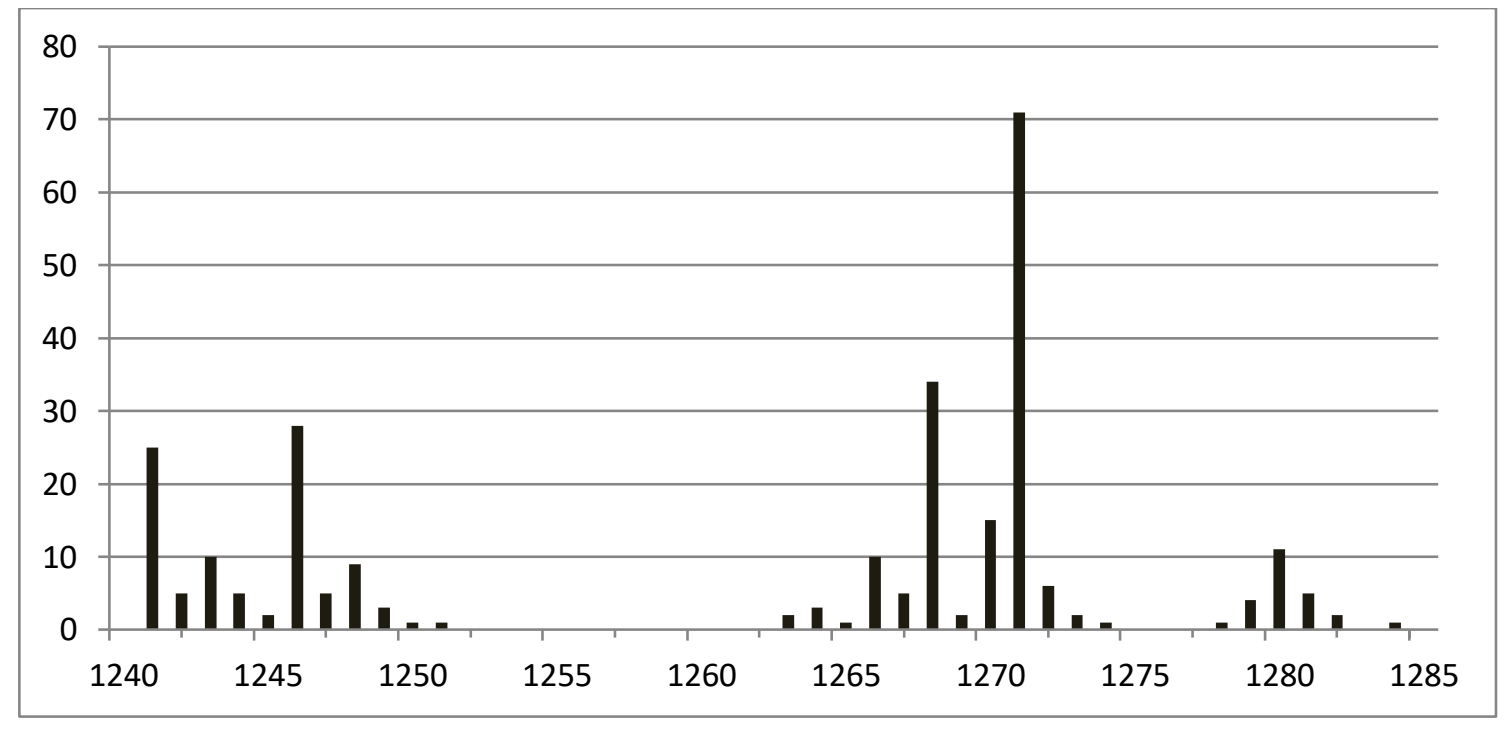

Graph 1. Number of plots established by years (1240-1285) in Saint-Mathieu district

\footnotetext{
${ }^{52}$ In principle, the Perpignan command post ruled the capital of the Temple of Roussillon at the same time as the Masdéu command post, which does not exclude a certain degree of subordination, as can be inferred from the fact that the preceptor of Perpignan sometimes acted as lieutenant to the Masdéu preceptor.
} 
As might be expected, there was a very large number of beneficiaries, almost as many as the number of leases recorded, as very few are listed as having received more than one plot. ${ }^{53}$ And although many of them are already listed as inhabitants of Perpignan, it is clear that they came from other villages in Roussillon - such as Malloles - as well as from the Conflent area. This does not exclude other origins south of the Pyrenees. ${ }^{54}$ As Tréton pointed out, it has been shown that adjacent plots of land were allocated to people from the same geographical area; ${ }^{55}$ all of this could point to waves of immigrant family groups arriving in Perpignan, especially during the 1240s. Many of these beneficiaries were craftsmen (as far as the building trade goes, several carpenters and at least one stonemason are mentioned), ${ }^{56}$ but there were also market gardeners (and labourers), cartwrights, and the odd miller, baker, and butcher. ${ }^{57}$ Once they had settled, each of them would start to ply their trade, either in the newly-built house or in other more remote premises, depending on the type of trade involved; be that as it may, the new craftsmen's quarter outside the walls was gradually equipped with all the necessary services, almost as if it were an independent town. The Order itself must have been interested in attracting a variety of craftsmen of all kinds; indeed, in some cases, the main reason why people were given a plot of land by the Knights Templar may have been precisely that they had a trade. However, there is also evidence of other professions, including a scribe (Jaume

\footnotetext{
${ }^{53}$ One could mention the case of the tailor Ramon Barrot, who appears successively as the beneficiary of three courtyards acquired in 1241, 1246, and 1264, on this last occasion accompanied by his son Ponç.

54 There were several people from Ripoll such as Bartomeu Corretger and his wife Berenguera, and other Corretger (Arnau) and his wife Ermessenda, coming from Sant Joan de les Abadesses, near Ripoll.

55 Tréton, Diplomatari, I:143.

${ }^{56}$ Diplomatari del Masdéu, doc. nos. 653 and 659. The stonemason (lapidarius), Ramon Pau, received two plots of land at different times in 1266.

${ }^{57}$ During this period, the leather tanning sector was predominant, followed by carpenters in the construction sector. In the percentages of Verdon, "Le quartier Saint-Mathieu," 104, trades linked to leather work represent $42.1 \%$ of the artisan population, the textile sector $7.8 \%$, carpenters $36.8 \%$, and transporters $2.6 \%$.
} 
d'Olesa), who called himself the herald of the King of Mallorca, and a jurisconsult (Guillem Paraire), but only at the end of the timeline in question. The fact that these sorts of people settled here could be a sign that this recently developed area had begun appealing to wealthier people. ${ }^{58}$

The plots of land given to all these individuals are usually defined by the same word, albeit with variations, depending on whether it is expressed in Latin (patuum), Catalan (pati/patil), or even in a sort of middle ground (patui/patuo) ${ }^{59}$ Interestingly, the records also usually give the measurements of each plot. ${ }^{60}$ These measurements are expressed a few times in Narbonne or Montpellier canas, which would be equivalent to almost two metres $(1.98 \mathrm{~m})$; otherwise, the unit of length was the monallada. This term is derived from monall, which is a type of beam. According to Tréton, it was a standard measurement as a multiple of the cana, supposedly equivalent to five metres $(4.97 \mathrm{~m})$. Thus one monallada would be two and a half canas, and one square monallada would be equivalent to an area of about twenty-five $\mathrm{m}^{2}$.

However, the interpretation of these measurements raises certain questions; the records very often only indicate a number of monalladas (up to a maximum of twelve), sometimes accompanied by the adjective "complete;" so for example, a plot of two complete monalladas would be fifty $\mathrm{m}^{2}$. Could this be extrapolated to all other two monallada plots that are not explicitly indicated this way? The problem does not arise when two different figures are given for the width and length of the plot. Table 1 shows

\footnotetext{
${ }^{58}$ Also worth noting is the presence of at least one Jew (Salomó Deulocrega) in the long list of beneficiaries in 1271 .

${ }^{59}$ All these words refer to courtyards. On at least one occasion (1281) the equivalence patuum sive solum is given.

${ }^{60}$ In this respect, there is a significant gap in most of the grants made in 1246, in twentyfive of the twenty-eight recorded for that year.
} 
the different combinations possible, in order to figure out which were most frequent (excluding the combinations mentioned only once, such as $3 \times 3,2.5 \times 6$, and $4 \times 6$ ):

Table 1. Different sizes of plots measured in "monalladas."

\begin{tabular}{lccccccccc}
\hline $\begin{array}{l}\text { width by } \\
\text { length }\end{array}$ & $1,5 \times 1$ & $1 \times 2$ & $2 \times 2$ & $4 \times 2$ & $1 \times 4$ & $1,5 \times 4$ & $2 \times 4$ & $2,5 \times 4$ & $3 \times 4$ \\
\hline $\begin{array}{l}\text { number of } \\
\text { plots }\end{array}$ & 4 & 19 & 2 & 4 & 38 & 17 & 13 & 3 & 2 \\
\hline
\end{tabular}

Plots were generally rectangular (a very few were square), and their surface areas differed greatly: the most widely-used combination was a plot one monallada wide by four monalladas long; even so, this only refers to $36 \%$ of the total number of plots measured in this way. As for the other unit of length (Narbonne/Montpellier canas), ${ }^{61}$ we find combinations of $2.5 \times 6,2.5 \times 2.5$, and $4 \times 4$, as well as a couple of mixed combinations. $^{62}$

There is yet another possibility, which is when the number of monalladas is indicated together with the width and length measurements; so two monalladas would be the equivalent of plots measuring of $1 \times 2,2 \times 4$, or $1 \times 4$. No set rule can be inferred in this regard. ${ }^{63}$ For the same reason, more extensive calculations cannot be made for the whole set of recorded plots.

This all shows that some of these plots were much larger than usual, such as the two plots leased in 1268 and 1271, which measured twelve monalladas (equivalent, in principle, to $300 \mathrm{~m}^{2}$ ). Both were surrounded by streets on all sides, so one could guess,

${ }^{61}$ These canas were only used in the first three establishments of 1215 and were two of $5 \times 5$ and one of $12 \times 5$.

${ }^{62}$ In one case, one and a half monalladas by ten and a half canas, Diplomatari del Masdéu, doc. no. 653; in the other, one monallada by ten canas, Diplomatari del Masdéu, doc. no. 772 .

${ }^{63}$ Whenever it is mentioned as two complete monalladas, the only equivalence indicated (on at least three occasions) is with the more usual combination of $1 \mathrm{x} 4$. 
as Tréton does, that they formed a block within their respective orthogonal structure. ${ }^{64}$ These kinds of plots of land were far from even; however, the plot that is mentioned most (1x4 monalladas) could be taken as the standard. Assuming that one monallada was equivalent to $4.97 \mathrm{~m}$, this plot would have been $4.97 \mathrm{~m}$ wide ${ }^{65}$ by $19.87 \mathrm{~m}$ long, giving a total surface area of almost 100 square metres $\left(98.75 \mathrm{~m}^{2}\right) .{ }^{66}$ As can be concluded from the archaeological surveys carried out in a sector of that neighbourhood, not all of the available surface area would have been used to build the future dwellings. Instead, some space would have been left unbuilt — perhaps back courtyards — and this seems to be more in line with the measurements provided by archaeologists. ${ }^{67}$ The fact that they had to build dividing walls with other neighbouring plots is also evidence that they were semidetached houses. ${ }^{68}$ As for the materials, the records refer to adobe being used, judging by the indication related to a courtyard granted to Pagà Fuster in $1249 .{ }^{69}$ In other cases, there are mentions of the use of tiles for roofing these houses. ${ }^{70}$

As has already been said, this division was carried out gradually in the area that the Order had been acquiring outside the walls, in the often invoked "tenancy of the

${ }^{64}$ For hypothetical measurements of each block and the lengths of the streets, see Tréton, Diplomatari, 141-43, with reference to the town planning study by Antoine de Roux.

${ }^{65}$ It is generally assumed that the width of the façades was limited by the length of the wooden beams used; unless two or more bodies were joined together, the distance between main walls could not exceed five $m$ in width.

${ }^{66}$ For the standard size of the plots as two monalladas, i.e., $50 \mathrm{~m}^{2}$, see Rémy et al., "Des maisons en terre," 59. Sabaté, Història de Lleida, 346, attributes to each "plaça" an area of almost $90 \mathrm{~m}^{2}$, which could contain up to four dwellings, each measuring just $22.31 \mathrm{~m}^{2}$. ${ }^{67}$ Rémy et al., "Des maisons en terre," 75. With measurements of $5 \times 9$ (or 5x10) and an average surface area of between $45-50 \mathrm{~m}^{2}$.

${ }^{68}$ In the case of Pere Despuig, Diplomatari del Masdéu, doc. no. 656, he was given permission to build on the neighbour's wall on the south side.

${ }^{69}$ Diplomatari del Masdéu, doc. no. 503. The phrase in question (I monallatam de tovo, preter parietes, in latitudine) presents some difficulties of translation, but the most important aspect is the reference to the material used (tovo).

${ }^{70}$ Precisely in 1250, according to Rémy et al., "Des masions en terre," 57, the preceptor of the Temple is documented as having granted to Pagà Fuster himself a tile kiln outside the Malloles gate. 
Temple." The first three establishments in 1215 were located in a vineyard owned by the Order near the Malloles gate. ${ }^{71}$ These location references are repeated from 1241 onwards, including some further details: for example, with regard to plots located in the Temple's orchard or trilla, as well as in other fields that the Order owned in that sector. Other boundary indications bear the names of the people who had been allocated a plot of land, enabling us to reconstruct some rows of leased buildings (Figure 5). ${ }^{72}$

[N] New Street

\begin{tabular}{c|c|c|c|c|c|c|c|c|c|c}
\multicolumn{1}{c|}{$\begin{array}{l}\text { [O] } \\
\begin{array}{l}\text { Franciscans } \\
\text { / Temple Street }\end{array}\end{array}$} & 1 & 2 & 3 & 4 & 5 & 6 & 7 & 8 & 9 & 10 \\
\end{tabular}

[S] Street
1. Joan Vel, tanner
2. Pagà Fuster
3. Pere Codoal
4. Arnau de Campelles
5. Bernat de Siurana
6. Ermengol de Forques, leatherworker
7. Guillem Fabre de Castell-rosselló
8. Ponç de Cotlliure
9. Guillem de Cotlliure
10. Bernat de Prissilans

${ }^{71}$ Tréton, Diplomatari, doc. no. 330, 1019-21. The records show that between 1215 and 1241, specifically in 1233, Nuño Sanç, Lord of Roussillon, donated a "solum sive pati" to Garcia Reboster in the same area, next to the houses of the Temple. Garcia Reboster's tenancy later appears bordering other plots.

72 Tréton, "L'ordre du Temple," 273-74, makes two attempts to reconstruct the plots from a more realistic point of view: the first for the plots established in 1215 next to the Malloles gate and the second for the 1241 section located next to the minor friars convent. The latter is the longest section that can be reconstructed. 


\section{[N] Street}

\begin{tabular}{l|l|l|l|l|l|l|l|}
\hline 1 & & & & & & \\
& 2 & 3 & 4 & 5 & 6 & 7 & 8 \\
\hline
\end{tabular}

[S] Tenency of the Temple
1. Joan Vilavedre
2. Guillem Crosses, young, carpenter
3. Joan Fabre de Sala
4. Guillem [Fabre] de Sala
5. Guillem Fabre de Pinell
6. Bernat Cairó, shoemaker
7. Arnau Piquer
8. Ramon Barrot, tailor

1243

[N] Tenency of the Temple

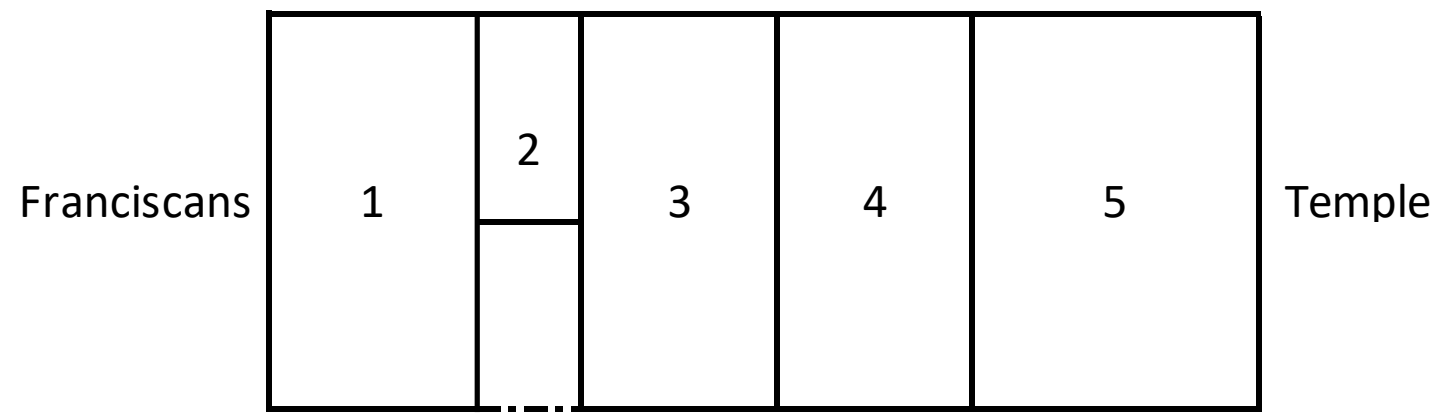

[S] New Street
1. Pagà Fuster
2. Guillem Crosses
3. Arnau de Fontcoberta
4. Pere Carles
5. Guillem Fabre de Castell-rosselló 
Figure 5. Reconstruction of some sections of the plots of the new Perpignan district of Sant Mateu with the name and profession of each tenancier.

In addition, several sides of many plots opened onto public roads, including in the 1240s a via novella, which local historians have identified as being the present-day street of Mariscal Foch, which was the old Malloles road. All of this gives an idea of how the road system was developing, just as the different islands or blocks of buildings on their respective built-on plots were also being defined, albeit surely without any preconceived long-term plan, let alone a global plan for the whole area through which these properties were being developed.

All these plots were given ad faciendum ibi domum vel domos or other similar expressions suggesting the building of one or several houses. The conclusion, then, is that the plot was given for a single building; this could imply several houses, hence the lack of definition of the term "domus." The house also had to be built within a certain period of time, and this is indicated quite systematically from 1265 onwards. For instance, Arnau Jordà de Bellpuig was given four years to build his house and, if he failed to do so, he would have to pay the Order a fine of twelve and a half Barcelona solidos as a penalty; in three or four other leases, only one year is given, and in all others the time limit is two years. Once this limit had passed, the building had to be at least fit to be lived in; otherwise, the Order would repossess the land and give it to someone else.

Some cases include other, more specific terms and conditions. For example, in many of the leases given during the first stage (until 1245), the tenant was given the right to drain the water towards the Templars' tenancy. Later, it was forbidden to put sewers or water pipes in the plots located next to the Temple's orchard, and the tenant was banned from opening windows or having viewpoints on that side, as a way of preserving the neighbour's privacy. One highlight is the lease given to the stonemason Ramon Pau, 
which features a whole raft of conditions. ${ }^{73}$ First of all, the new tenant had to build a blind wall on the side facing the Templars' orchard, where he could not install any sewer or conduit (stillicidium sive aquaversum), but he could cover the dividing wall with tiles. Only if the Templars were to give someone else the part of the road between the orchard and the plot in question, would he be allowed to open doors and build a partition wall (envannuum). Finally, he was banned from building a lime kiln. Pere Despuig, a tanner by trade, was subject to similar conditions, including a ban on building a tanner's tank or causinerium, needed for those who dealt with hides ${ }^{74}$.

As this example shows, some of the conditions were imposed in anticipation of future buildings that might be erected on the adjoining land. That is why, in several of the leases given in 1280, the Templars undertook that, if the part of the trilla adjoining the plot was given en acapte, they would allocate part of it to building a public road to allow the tenant to access his dwelling; until this happened, he was given permission to drain his water onto the Temple's property. Apart from guaranteeing a right of way to let everyone access their respective plots, there seems little doubt that it was the Order that planned both the plots and the layout of the streets in between them, not in line with an overall plan, but rather partially, as the area was developed. ${ }^{75}$

Hardly any reference is made in the records to the materials used to build these houses. An archaeological study carried out on a sector of the neighbourhood clearly shows that these houses were basically built of bricks, which could be due to reasons economic (lower costs), social (the tenants' modest origins), or cultural (models imported

\footnotetext{
${ }^{73}$ Diplomatari del Masdéu, doc. no. 153. See also Tréton, Diplomatari, I:140.

${ }^{74}$ Diplomatari del Masdéu, doc. no. 656.

75 According to Vinas, "Els templers," 72, however, the new roads mentioned before the constructions indicate the existence of a previous plan.
} 
from other regions) ${ }^{76}$ Considering not only the case of Perpignan but also that of other towns in Roussillon, Rémy concludes that the use of adobe or bricks was more widespread than had been thought. On top of this came the need to build quickly at a time of strong demographic expansion, like the one that occurred in the mid-thirteenth century. ${ }^{77}$ In any case, the generally established two-year deadline for building these houses would be perfectly feasible by using materials that were more manageable or easier to use, and also easier to obtain. Thus, rather than building to last, it was about building quickly from poor materials in order to give shelter to people of modest means, from which an evident relationship between type of construction and social condition is extracted. In this sense, the work of archaeologists is essential to reach where written documents cannot.

As to what these houses were like on the inside, they are assumed to have been divided into three floors: a first floor, probably reserved for trade or commercial uses; a second floor, which would be where people actually lived; and finally an attic, perhaps used as a storeroom, with a single-slope roof facing the street. These were otherwise modest houses, as befit the social status of most of the original inhabitants. ${ }^{78}$

As mentioned above, the number of building plots was decreasing in the 1280s. By then, as Vinas noted, at the same time as the kingdom of Mallorca, with its capital in Perpignan, came into being, the new district must have been practically built to its full

\footnotetext{
${ }^{76}$ Rémy et al., "Des maisons en terre," 62, 73, suggest a possible transfer from south of the Pyrenees, that is, from Catalonia itself or other areas of the Iberian Peninsula.

77 Canal et al., "Masoveries," 161. In Girona, of the seventy-eight establishments documented in the thirteenth century ad construendum domos, at least thirty were built between 1240 and 1260 .

${ }^{78}$ Vinyoles, "La vida quotidiana," 137 . In essence, they would not be very different from those described by Vinyoles in the case of Barcelona, but with a few variations (the roof was usually double-sloped or even flat, like a roof terrace); however, it is also considered that as a general rule they would have been built with adobe.
} 
extent. ${ }^{79}$ It would not be an exaggeration to consider that the Order of the Temple, in prompting the development of the craftsmen's quarter, was responsible for a large part of the prosperity achieved by this town at the end of the thirteenth century, as the main town centre of Roussillon and its booming merchant and manufacturing business (Figure 6).

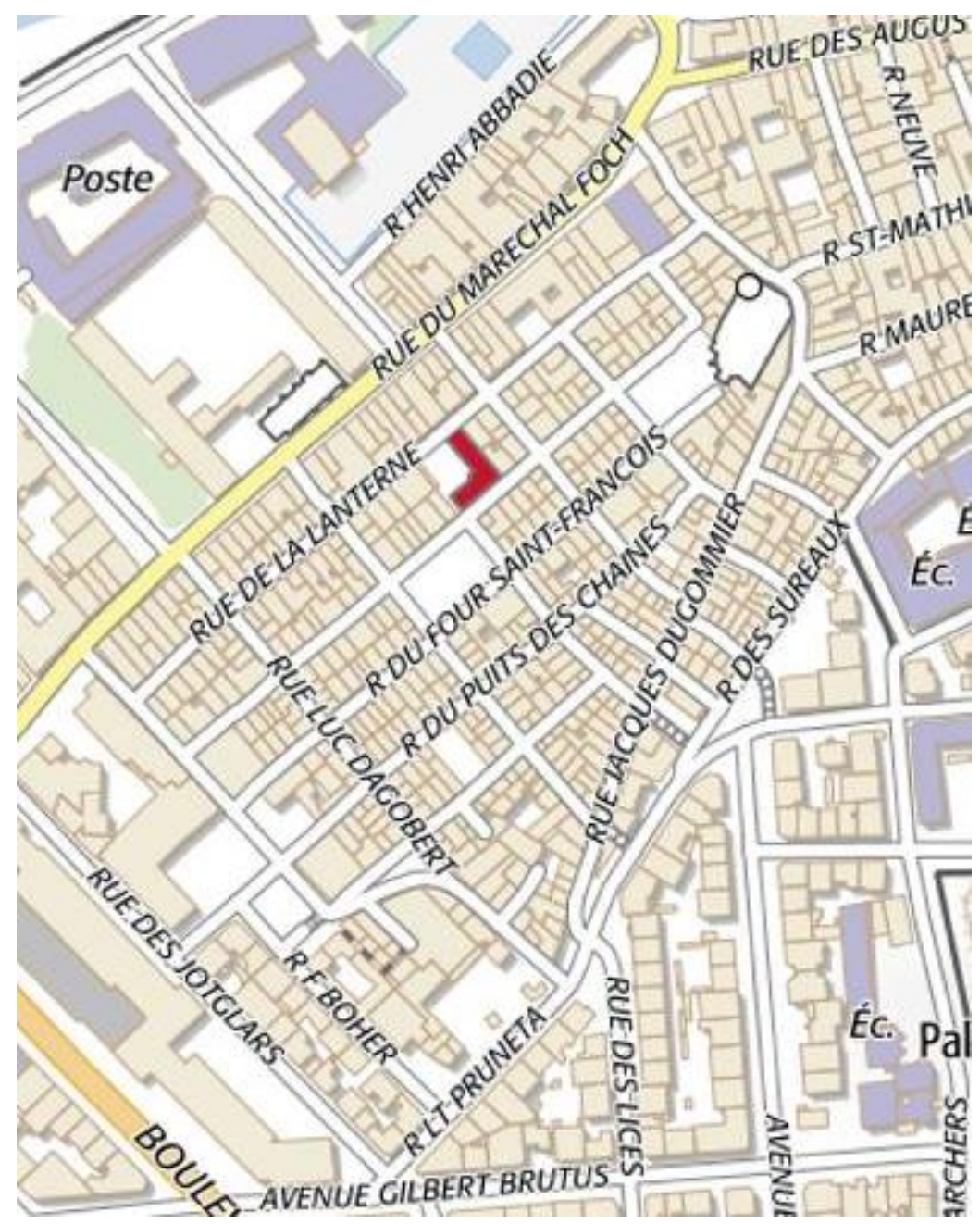

Figure 6: The Perpignan district of Sant Mateu as it is today. The neighbourhood, which occupies about seven hectares, was formed between what are now the streets of Maréchal Foch and Dugommier. The present-day plan still shows the grid layout of the Templar era (see Fuguet, Els templers, 129). Source: Géoportail.

${ }^{79}$ Vinas, Els templers, 72. The neighbourhood in question was included within the new walled enclosure of the town, which began to be built in 1277 . 


\section{Conclusions}

Although it may be that the four cases examined in this article cannot be fully extrapolated to other territories, they are illustratives examples of the usual way of promoting housebuilding in medieval Catalonia. In addition to ensuring the settlement of populations through the spatial organisation of plots of land, these construction processes can be taken as paradigms, in turn, for the territorialisation of medieval society and also, to some extent, as an investment in social identity, above all for the working classes, that is, those who became inhabitants of these places and who, over time, also acquired a series of community obligations and rights. Thus, masonry could become an instrument to display each community's identity; in fact, this era was a time for the formation of collective identities: the whole country was under construction, not only in the literal sense of the expression but also figuratively.

This article has focused on the donations of plots of land for building houses ( $\mathrm{ad}$ construendum domos) because these emphyteutic leases can serve to gauge the extent of the building boom that seems to have been present everywhere, as a phenomenon inseparable from the context of twelfth- and thirteenth- century demographic and economic growth. The impetus given to the building of houses or dwellings can be traced both in the creation of the viles noves, which sometimes sprang up next to pre-existing centres of population, and in the expansion of the different burghs or neighbourhoods set up outside the city walls; in the latter, more parties tended to be involved. Timelines drawn from the different cases show that their housing development peaked in two main phases: the first, around the turn of the thirteenth century, just as lords were granting municipal charters, and the second, in the mid-thirteenth century, when it peaked even more strongly in the cities or centres that appealed most to the population. 
It seems evident that housebuilding was an enterprise generally directed or supervised by the great lords who owned the land. At the forefront of the developers who leased out most plots of land were ecclesiastical institutions. The actions taken by the cathedral chapter of Tortosa, the Canonry of Guissona, or the Templars of Gardeny and Masdéu - each in their respective areas of influence - can be extrapolated to many other religious establishments in the larger region, as in the case of the Abbot of Poblet in Vimbodí, and also to the military orders. ${ }^{80}$ These institutions' actions overshadow the role that lay developers may also have played, starting with the crown and continuing with other noble lords. To a large extent, this can be explained by the nature of the documentation preserved for that period, which was, as a general rule, produced at the behest of religious institutions. They are recorded as having granted most of the plot leases, but such work may also have been entrusted to other individuals, who acted as real estate agents, as has been demonstrated for Girona in the thirteenth century and for Valencia around the turn of the fourteenth. Furthermore, it has been seen that each ecclesiastical entity operated in certain areas, generally close to the place where they had their respective sites or headquarters; subsequently, all these areas of urban expansion ended up being encompassed within the new walled enclosures.

The degree of planning in the different actions taken by the lords seems more than evident, but in some cases more so than in others. As we have seen, Riudovelles was an operation that involved occasionally transferring different groups of colonists to settle in a new location for the purpose of concentrating scattered populations in certain enclaves that had already been parcelled out. However, in the longer-lasting processes of urban environments, housing development seems to have taken place gradually and without

${ }^{80}$ Jaspert, "Military Orders," 22, points out that the Orders "contributed to and profited from urban expansion in much the same way other urban institutions of their time did." 
being planned in detail by the lords. Yet the creation of the Perpignan district of Saint Mathieu is representative of full-fledged planning, at least in the short-term, depending on the successive batches of tenanciers (terratgers) that the Order had settled in the area, until the district was completely inhabited.

As for the size and shape of leased plots in urban areas, they tended to be elongated and rectangular, arranged perpendicularly to a street. In the case of Saint Mathieu in Perpignan, the estimated average size of leased plots was around $100 \mathrm{~m}^{2}$, although not all of the surface area was built on. However, the operation was far from a uniform process, if one considers all of the plots recorded and their different sizes. Very simple houses were built on these plots, in keeping with the social status of their settlers, at least during the first period, when the area was populated by people with different trades. In fact, the main characteristic of these houses would have been the use of poor materials, such as adobe, associated with building techniques that were easier for people to do on their own. This would explain the relative speed with which these dwellings had to be built; the general two-year time limit must have been considered the appropriate for completing the work.

In fact, the tenanciers themselves may have been the builders in the literal sense of the word; anyone could build a house with just a few manual skills, without having to ask for much outside help, and only the wealthiest could afford to hire professionals to do work of this kind. The fact is that the lords provided the land, but it was the individuals who were responsible for building and investing in the construction of their own houses, whether or not they were builders themselves.

The case of Perpignan highlights other realities or forms of shaping the landscape that until now have gone almost unnoticed due to the priority given to buildings built 
entirely of stone, which were the only ones designed to last as long as possible. Indeed, the use of poorer materials explains why dwellings were harder to preserve. If they have not disappeared altogether, they were remodelled in later centuries and so have changed greatly. All this led to a radical transformation of the landscape or, more specifically, of the landscapes around these ever-larger towns and villages, as farming areas became developed and a large number of dwellings were built on them, together with the most essential community services. The development of the Saint Mathieu district of Perpignan was such a huge real estate operation that it is hard to find any other comparable documented case in Catalonia. It is paradigmatic not only of urban expansion, but also of the significant economic growth that this town in Roussillon was to experience, especially from the end of the thirteenth century.

The housing development in the towns studied here (Tortosa and Perpignan) only reflects the early stages of town planning. As new land was built on, other types of transactions would come to the fore, either sale-purchases or transfer of the beneficial ownership, or through new leases and/or sub-leases, ${ }^{81}$ or even through the commercialisation of the rents raised on these properties. The consolidation of this booming market reinforced a business in which an essential role was played by third parties, who became involved as real estate agents. Such a process would not have been possible, however, without the efforts of the great owners, who provided land for development on a greater or lesser scale.

${ }^{81}$ In the case of Girona, urban masoveries refer to the rental contracts signed with the dwellers of these houses. See Canal et al., "Masoveries, lloguers, inquilins." 


\section{Works Cited}

\section{Primary Sources}

Alturo, Jesús, ed. L'Arxiu antic de Santa Anna de Barcelona del 942 al 1200. 3 vols., Col. Textos i Documents, 8-10. Barcelona: Fundació Noguera, 1985.

Font Rius, Josep M. Cartas de población y franquícia de Cataluña, vol. I-II. MadridBarcelona: CSIC, 1969-1983.

Galera, Andreu, ed. Diplomatari de la vila de Cardona (966-1276). Col. Diplomataris, 15. Barcelona: Fundació Noguera, 1998.

Marquès, Benigne. "Els pergamins de Santa Maria de Guissona, 1266-1283." Urgellia 19 (2015-2018): 333-409.

Riu, Manuel. "Documents del Archivo Histórico Nacional de Madrid, referents a monestirs i canòniques del bisbat d'Urgell.” Urgellia 10 (1990-1991): 351-73.

Sangés, Domènec. "Els documents del segle XII (1176-1200), del fons de Guissona, conservats a l'Arxiu Diocesà d'Urgell." Urgellia 15 (2002-2005): 211-336.

Sangés, Domènec. "Els documents del segle XIII (1201-1225), del fons de Guissona, conservats a 1'Arxiu Diocesà d'Urgell." Urgellia 16 (2006-2007): 171-334.

Sangés, Domènec. "Els documents del segle XIII (1226-1240), del fons de Guissona, conservats a l'Arxiu Diocesà d'Urgell." Urgellia 17 (2008-2010): 135-224.

Sarobe, Ramon, ed. Col-lecció diplomàtica de la Casa del Temple de Gardeny (10701200), vol. I. Col. Diplomataris, 16. Barcelona: Fundació Noguera, 1998.

Tréton, Rodrigue, ed. Diplomatari del Masdéu, vol. I-V. Col. Diplomataris, 52-56. Barcelona: Fundació Noguera, 2010.

Virgili, Antoni, ed. Diplomatari de la catedral de Tortosa (1062-1193). Col. Diplomataris, 11. Barcelona: Fundació Noguera, 1997.

Virgili, Antoni, ed. Diplomatari de la catedral de Tortosa (1193-1212). Episcopat de Gombau de Santa Oliva. Col. Diplomataris, 25. Barcelona: Fundació Noguera, 2001.

Virgili, Antoni et al., eds. Diplomatari de la catedral de Tortosa. Episcopats de Ponç de Torrella (1212-1254) i Bernat d'Olivella (1254-1272), vol. I-II. Col. Diplomataris, 7677. Barcelona: Fundació Noguera, 2018. 


\section{Secondary Sources}

Alsina, Claudi, Gaspar Feliu, and Lluís Marquet. Pesos, mides i mesures dels Països Catalans. Barcelona: Curial, 1990.

Banks, Phillipe. "L’articulació urbana de Catalunya." In Jaume I. Commemoriació del VIII centenary del naixement de Jaume I, vol. 2, edited by M. Teresa Ferrer i Mallol, 89105. Barcelona: Institut d'Estudis Catalans, 2013.

Banks, Phillipe. "El creixement físic de Barcelona. Segles X-XIII." Quaderns d'Història 8 (2003): 11-33.

Bolòs, Jordi. Els orígens medievals del paisatge català. L'arqueologia del paisatge com a forma per a conèixer la història de Catalunya. Barcelona: Abadia de Montserrat, 2004.

Bolòs, Jordi. "Paisatge i societat al Segrià al segle XIII." In Paisatge i societat a la Plana de Lleida a l'Edat Mitjana, edited by Jordi Bolòs, 45-81. Lleida: Universitat, 1993.

Canal, Eduard, Josep M. Nolla, and Jordi Sagrera. Girona en el segle XIII (1190-1285). Cartografia i descripció de la ciutat medieval. Girona: Ajuntament, 2010.

Canal, Eduard, Josep M. Nolla, and Jordi Sagrera. "Masoveries, lloguers, inquilins. Edificació i lloguer en la construcció de Girona al segle XIII." Annals de l'Institut d'Estudis Gironins 59 (2018): 157-90.

Carraz, Damien. "Les commaderies dans l'espace urbain. Templiers et Hospitaliers dans les villes de l'Occident Méditerranéen (XII ${ }^{\mathrm{e}}-\mathrm{XIII}{ }^{\mathrm{e}}$ siècle)." Mélanges de l'École Française de Rome 124, no. 1 (2012): 119-36.

Corretgé, Fabià. "Les vilanoves segrianenques." Shikar. Revista del Centre d'Estudis Comarcals del Segrià 4 (2017): 86-93.

Eritja, Xavier. De l'Almunia a la Turris: organització de l'espai a la regió de Lleida (segles XI-XIII). Lleida: Universitat, 1998.

Farías, Víctor. "La fundación de villas en la Catalunya Vella (siglos XII-XIII). Una contribución al estudio regional de la urbanización a pequeña escala." In Ciutats, viles, sagreres. Els nuclis urbans a la Baixa Edat Mitjana (s. XIII-XV). Actes del II Seminari d'Estudis Medievals d'Hostalric (18-19 de noviembre de 2010, Hostalric), edited by Neus Puig and Montserrat Viader, 9-20. Hostalric: Ajuntament, 2011.

Feliu, Gaspar. "Algunes consideracions sobre la metrologia altmedieval." Acta Historica Archaeologica Mediaevalia 22 (2001): 121-49.

Fuguet, Joan, and Carme Plaza. "L'ordre du Temple dans la Couronne d'Aragon, aspects topographiques et archéologiques. Les cas de Tortosa et Barcelone." In Les ordres militaires dans la ville médiévale (1100-1350). Actes du colloque international de Clermont-Ferrand, 26-28 mai 2010, edited by Damien Carraz, 239-55. ClermontFerrand: Presses Universitaires Blaise-Pascal, 2013. 
Guilleré, Christian. "Gérone au temps de Jaume I ${ }^{\mathrm{er}}$." In Jaume I. Commemoriació del VIII centenary del naixement de Jaume I, vol. 2, edited by M. Teresa Ferrer i Mallol, 107132. Barcelona: Institut d'Estudis Catalans, 2013.Hubert, Étienne. "La construction de la ville. Sur l'urbanisation dans l'Italie médievale." Annales. Histoire. Sciences Sociales 1 (2004): 109-39.

Hubert, Étienne. "Urbanisation, propriété et emphytéose au Moyen Age." In Le sol et l'immeuble: les formes dissociées de propriété immobilière dans les villes de France et d'Italie (XII ${ }^{e}-X I X^{e}$ siècle), edited by Olivier Faron and Étienne Hubert, 1-8. Rome: École Française de Rome, 1995.

Jaspert, Nikolas. "Military Orders and Urban History. An Introductory Survey." In Les ordres militaires dans la ville médiévale (1100-1350). Actes du colloque International de Clermont-Ferrand, 26-28 mai 2010, edited by Damien Carraz, 15-36. Clermont-Ferrand: Presses Universitaires Blaise-Pascal, 2013.

Pagarolas, Laureà. La Comanda del Temple de Tortosa: primer període (1148-1213). Tortosa: Institut d'Estudis Dertosenses, 1984.

Pagarolas, Laureà. Els templers de les terres de l'Ebre (Tortosa). De Jaume I fins a l'abolició de l'Orde (1213-1312) 2 vols. Tarragona: Diputación, 1999.

Pladevall, Antoni, dir. L'art Gòtic a Catalunya: arquitectura. III: Dels palaus a les masies. Barcelona: Enciclopèdia Catalana, 2003.

Rémy, Isabelle, Patrice Alessandri, Aymat Catafau, and Claire-Anne de Chazelles. "Des maisons en terre médiévales sur un îlot du quartier Saint-Mathieu, à Perpignan (PyrénéesOrientales). Premiers éléments de réflexion." Archéologie du Midi Médiéval 27 (2009): 53-95.

Sabaté, Flocel, Història de Lleida. 2: Alta Edat Mitjana. Lleida: Pagès, 2003.

Sans Travé, Josep M. La colonització de la Conca de Barberà després de la conquesta feudal: el cas de Vimbodí (1149?/1151-1200). Montblanc: Cossetània, 2002.

Torró, Josep, and Enric Guinot. "De la madîna a la ciutat. Les pobles del sud i la urbanització dels extramurs de València (1270-1370)." Saitabi 51-52 (2001-2002): 51103.

Tréton, Rodrigue. "L'ordre du Temple dans une capitale méditerranéen: Perpignan." In Les ordres militaires dans la ville médiévale (1100-1350). Actes du colloque international de Clermont-Ferrand, 26-28 mai 2010, edited by Damien Carraz, 223-37. ClermontFerrand: Presses Universitaires Blaise-Pascal, 2013.

Verdon, Laure. "Le quartier de Saint-Mathieu de Perpignan: un exemple de la croissance d'une ville au XIII sièle." In La ciutat $i$ els poders. Actes du Colloque du Huitième Centenaire de la Charte de Perpignan, 23-25 octobre 1997, Louis Assier-Andrieu, dir., 99-107. Perpignan: Presses Universitaires de Perpignan, 2000. 
Vinas, Robert. Els templers al Rosselló. Lleida: Pagès, 2002.

Vinyoles, Teresa. "La vida quotidiana i l'espai domèstic al segle XIII." In Jaume I. Commemoriació del VIII centenary del naixement de Jaume I, vol. 2, edited by M. Teresa Ferrer i Mallol. Barcelona: Institut d'Estudis Catalans, 2013.

Virgili, Antoni. 'Ad detrimentum Yspanie': La conquesta de Turtusa i la formació de la societat feudal (1148-1200). València: Universitat de València, 2001.

Virgili, Antoni. "Els conqueridors de mitjan segle XII: com aprenen a ser-ho." In El feudalisme comptat i debatut. Formació $i$ expansió del feudalisme català, edited by M. Barceló, G. Feliu, A. Furió, M. Miquel, and J. Sobrequés, 253-92. València: Universitat de València, 2003. 